\title{
On Quality Education Reform in International Trade Major
}

\author{
Jing Ma \\ School of Economics and Management, Changchun University of Science and Technology \\ Weixing Road No. 7989, Changchun 130022, China \\ E-mail: majingdoll@hotmail.com
}

Jing Xiao

School of Economics and Management, Changchun University of Science and Technology

Weixing Road No. 7989, Changchun 130022, China

E-mail: christieshaw@sohu.com

Received: October 10, 2010 Accepted: October 19,2010 doi:10.5539/ies.v4n3p210

\begin{abstract}
The purpose of this paper is to analyze the existing problems of quality education of specialization of international trade in current colleges and universities of China, and then propose several pieces of corresponding suggestion on educational reform. According to the characteristics of college and university education, we shall emphasize on the importance of quality education. Finally, we bring forward a series of countermeasures and proposals on the aspects of lecture mode, bilingual teaching, and training practical operation ability on instruction of specialization of international trade.
\end{abstract}

Keywords: Quality Education, Teaching Reform, Specialization of International Trade

Preface

It is well known, the current financial crisis is spreading all over the world, which brings keener competition among enterprises nationally and internationally. And the competition for excellent employees, especially the persons with high quality, is rather necessary for most of enterprises. Therefore, human resource demand is increasing recently. However, the financial crisis also brings an amount of unemployment globally. China is absolutely not an exception with enormous graduates without jobs. That is what we should consider deeply. So it is very urgent for Chinese colleges and universities to reform quality education and propose corresponding countermeasures.

As for Chinese previous college and university instruction, the same instruction methods of various subjects remained even for several decades. A teacher speaks, and students take notes. This is called feeding teaching, which dominated the education world, and resulted in low-efficient teaching, poor-ability students, and lack of innovation. So we have to ask a question: Smart Chinese children have better achievements than that of American children in primary school and middle school. But why do Chinese engineers and technological staff is worse than American ones in scientific research and innovative ability? Actually, one of the important reasons is that Chinese college and university education have big problems. The education staff of the Ministry of Education of China and many colleges and universities is on the way of searching education reform approach. They have noticed the idea of quality education is suitable for education reform of colleges and universities. The quality education targeting on promoting integrated quality of students was firstly started in primary school and middle school in China. Through several-decade efforts and struggle, education staff of Chinese primary schools and middle schools has achieved great success. However, it is very difficult to reform college entrance examination system, so crucial success hasn't been reached. The theory of quality education has been proved by practice to be advanced education concept in accordance with the development of times. Furthermore, there is no pressure of entering a higher school for students in college and university, so the environment for implementing quality education is comparatively soft. So how do we reform the instruction in specialization of international trade according to quality education theory? We shall propose the following suggestion.

\section{Reading-discussion Teaching Method}

Study is the process of active running of individual thoughts, which can't be substituted by others. The subject of study is student. As the popular Chinese saying goes, "The master teaches the trade, but the apprentice's skill is 
self-made". It straight and directly interprets study is individual and self activity. A teacher plays an instructive role, which organizes, instructs, disabuses and answers questions during teaching process. Undergraduates have mastered good reading comprehension ability, so firstly they should be asked to read textbooks and relevant materials before lectures. Thus they could try to understand and absorb what they have read, and then sum them up. This method is much better than the previous one. After reading, the students need to be organized for discussion. They can describe their own thoughts and understanding on the knowledge, at the same time, listen to others and put forward questions in order for discussion and debate. The method not only improve teaching quality, but also promote students' self-learning ability, expressive ability, and ability of discovering and solving problems, which are much more important than knowledge itself. As far as specialization of international trade is concerned, the knowledge and information it contains are updated and change day by day, along with time going and times progressing. Therefore, mastering today's knowledge and information is not enough for students' future development. Here we have to emphasize what students should learn in school is not knowledge, but the ability of how to learn new knowledge.

\section{Case Teaching}

Case teaching is one of the main teaching methods of economics in many famous colleges in some developed countries. The subject of international trade is tightly closed to practice, especially international trade practice, international economic cooperation practice, international marketing, and so on. Therefore, the theoretical teaching around cases enable students deeply grasps important points. Practice has proved, for the students at any age and any grade, interest is the best teacher. Firstly, the application of case teaching can arouse students' interest of learning. As for simple and short cases, the teacher can organize class discussion and presentation, and give comments, summary and question-solving suggestion subsequently. However, with regards to long and complex cases, the teacher can design questions inside the cases. So that the students have to review materials bearing questions in mind in order to find out theoretical bases and resolve the questions. Thus, the students can not only master relevant theoretical knowledge, but also get improved in question analysis, question solving and practical ability. Afterward, the teacher needs to ask the students to sum up and write a summary paper or learning experience, which will deepen their grasp of what they have learned. In addition, current hot topics on financial news and international trade problems (such as anti-dumping, green barrier, low carbon economy), also can become discussion topics in class or after class. All these will make students care more about what is related to their major and help to establish good study habit for them.

\section{Bilingual Teaching}

As for the students in specialization of international trade, no matter graduates or postgraduates, in fact, most of them will be engaged in practice work in the future. The main employment direction will be custom, foreign trade companies, import \& export departments of large enterprises, etc. So the students have to be very good at English. Through the first two-year public English studying, many students have passed national CET-4 or CET-6. However, for practical foreign trade work, many people will find they haven't enough when they use knowledge. So why? Firstly, they are poor at oral English. Secondly, they are at low level of specialization English.

Traditional education neglected oral English teaching, which caused many high-English-leveled students become "dummy" when talking with foreign traders. Why can two Negroes fluently talk with each other by 2000 words at a street corner in New York? Why do Chinese students who hold over 6000 English vocabulary become dummy? The fact is that they are lack of language environment. However, when we don't have any English environment, we have to make every effort to create a suitable language environment for students' English learning. Of course, class must be a good place for that. The teacher needs to try his or her best to create more practice opportunities so as to cultivate students' English expressive ability. For instance, the students can make discussion on a hot topic in English, afterward, everyone give a report or presentation on that. After class, "English corner" and "English salon" can be organized in order to arouse students' English learning interest and improve oral English level and application ability of them.

One of the best methods of improving specialization English level is bilingual teaching. Although traditional specialization English teaching can help to enlarge students' English vocabulary and learn how to use specialization English, but the study efficiency is quite low and the effect is not that apparent. Specialization English teaching focuses on vocabulary, grammar, reading and composition, but is lack of specialization knowledge. Bilingual teaching can right complement this shortage. Bilingual teaching can improve not only students' English listening, speaking, reading and writing, but also specialization knowledge of their major, so we call it "killing two birds with one stone". Moreover, some translated books from English into Chinese can not exactly express the authors' real meaning. Of course, this is not the problem of translators' skill, but some sense really can not be explained in words only. However, through reading original textbooks in English, the students can learn the authors' real ideas or 
theories in deed so as to grasp the theoretical essence by penetrating it. Additionally, the teacher also can instruct students to fill in some import \& export documents in English by themselves and to translate some English articles, so that they can get enhanced in practical working ability.

\section{Society Integration}

In recent years, Chinese foreign trade develops rapidly along with a lot of new things. So it is not enough to hold several old textbooks for international trade teaching, which far fail to meet the requirement of trade development. We have to continuously introduce new ideas, new things and new questions into classes. One hand, what the students have learned wouldn't be so far as to be out of date as soon as they step out of college gate. On the other hand, it is a new approach to train students to solve practical problems. Furthermore, we need to often invite some economic specialists and business elites to give lectures as well, in which they could introduce their practical experiences and key of success. Simultaneously, we should try to create good conditions for students to investigate and practice in financial and trade companies, so that they can get sensible recognition on practical work.

\section{Conclusion}

Driving by education reform idea in this new age, many colleges and universities of China are making every effort to reform education system and teaching approaches, which leads to quite a lot new methods and new forms. We also hope we can contribute to the education reform of specialization of international trade through several pieces of suggestion. And hopefully this paper can produce some modest contribution to cultivating high-quality talents in the field of international trade for China.

\section{References}

Li, Binglin. (2007). A comparison on "International Economics and Trade" curriculum and practical teaching between China and USA. The contemporary economy (second half), 06.

Fang, Kai. (2007). Training program improvement on specialization of international trade. The contemporary economy (second half), 09.

Guo, Pikuan. (2009). Training patterns on high-end talents in international trade field. Unions Forum, 02.

Li, Jiayuan. (2001). A study on quality education in the United States. Transaction of Guangxi College of Finance, 01 .

Song ,Yafei. (2001). The features of quality Education in the United States. Higher education research, 04.

Wu, Fengqing. (2000). The long-term, necessity and practicality of higher quality education in China. Journal of Hebei University of Technology, 01.

Li, Ruiyong. (2002). Ideological and Political Education is the soul of Higher Education. Hebei Institute of Technology (Social Sciences), 01.

Zhang, Libing. (2003). Problems and solutions on promoting quality education in colleges and universities. Decision and Exploration, 08.

$\mathrm{Wu}$, Wenbing. (2002). On improving the quality of university teachers and vigorously cultivating creative talents. Traffic Education Research, 02. 